\title{
ANALYZING THE UTILITY OF AUTHENTIC MATERIALS FOR DEVELOPING COMPREHENSION SKILLS AT INTERMEDIATE LEVEL
}

\author{
Muhammad Safdar Bhatti ${ }^{1}$, Asif Iqbal ${ }^{2}$, Zahida Javed ${ }^{3}$ \\ ${ }^{1}$ TEFL Coordinator, AIOU Bahawalpur, Pakistan, safdarbhatti2001@gmail.com \\ ${ }^{2}$ Asst. Prof. Dr., Education, GC University Faisalabad, asifphd@hotmail.com \\ ${ }^{3}$ Lecturer Education, GC University Faisalabad, zahidajaved@outlook.com
}

\begin{abstract}
English has won the status of International language. Due to its pivotal status, many nations are adopting it as their second language. Efforts have been made to boost up the standard of English Language teaching and learning in Pakistan. Authentic materials are good tools for developing comprehension skills. The current paper analyzes the utility and effects of authentic materials for developing comprehension skills among the students of intermediate level. Foci of the research remained towards the common problems of the students and the teachers while using authentic materials. It was an experimental type research that explored the impact of authentic materials on comprehension skills. Fifty students of intermediate level participated in the study. Pre-test, post-test experimental design was used and students' result was collected. The findings of the study elicited the meaningful implications for the use of authentic materials and students performed significantly. The researchers' conclusion with suggestions and recommendations were summed up at the end of the study.
\end{abstract}

Keywords: Authentic Materials, comprehension skills, pre-test, post-test experimental design

\section{INTRODUCTION}

English is taught as a compulsory subject in Pakistani educational institutions. Despite the fact that the students study it over several years, English may not have many applications beyond school settings. Several studies have revealed that the students do not have enough exposure to English language. As a result, their English language skills remain poor when they drift into college. This may be due to the methods of language teaching and learning environment which may be unsuitable for learning a foreign language.

In order to deal with the students' low English language proficiency, one solution was that teachers must stimulate real word situations in the classroom (STERN, 1981). Exploiting this situation may be the best use of Authentic Materials and examples of such materials include newspapers, magazines, T.V programs, radio talks, menus, brochures, novels, comics, short stories, weather forecasts, and recipes (Hedge, 2000). A growing mass of research has reported that Authentic Materials in the classrooms are effective resources that can positively contribute to students' progress.

Adams (1995, P.4) defines Authentic Materials as "Any material which has not been specifically produced for the purpose of language teaching". Guariento and Morley (2001, p. 347) define an Authentic Material as "an 
authentic text.... created to fulfill some special purpose in the language community in which it was produced". Also, the term 'authentic' was used "to refer to language samples that reflect a naturalness of form and an appropriate of cultural and situational context that would be found in the language as used by the native speakers" (ROGERS and Medley, 1988, p. 468). In a similar sense, Lee (1995, p. 324) describes that "a text is usually regarded as textually authentic if it is not written for teaching purposes, but for a real life communicative purpose, where the writer has a certain message to pass on to the reader".

One of the words that have been creeping into English teaching in the past few years is 'authentic'. It has a kind of magic ring to it: who after all would want to be inauthentic? It sounds as if any committed teacher must try to be authentic, and that the students' development in their new language is bound to be handicapped if it does not give them authentic experiences. Is authenticity really such a magic word? Should teachers feel guilty about being inauthentic? The advantages and uses of authentic materials will answer all these questions.

We have been using authentic materials for over 10 years and have found that they complement English classes by enlivening the class and creating a more positive attitude toward learning. We now have an extensive collection of materials that include menus, maps, newspaper inserts, store advertisements, travel brochures, Catalogs, phone books, real estate pamphlets, and various pamphlets of sightseeing and tourist information. We have found that using sets of materials are particularly appealing. A set could include a map, a travel guide, a menu, and a store advertisement from the same town-all of which are interwoven, immersing the student in a multidimensional English experience (Medley, 1987).

Using authentic materials is one of the mainstays of an imaginative and motivating higher level course, but rarely features at levels lower than intermediate. There are several reasons of this, primarily a kind of fear that students will panic when faced with language that is largely unfamiliar, and a feeling that prevents this language should be edited to the students' level. This is an unnecessary fear, as using authentic materials can be rewarding and stimulating for both teacher and students (Emerson, 2004).

The use of authentic materials in an EFL classroom is what many teachers involved in foreign language teaching have discussed in recent years. We have heard persuasive voices insisting that the English presented in the classroom should be authentic, not produced for instructional purposes. Generally, what this means is materials which involve language naturally occurring a communication in native-speaker contexts of use, or rather those selected contexts where Standard English is norm: real newspaper reports, for example, real magazine articles, real advertisements, cooking recipes, horoscopes, etc. Most of the teachers throughout the world agree that authentic texts or materials are beneficial to the language learning process, but what is less agreed is when authentic materials should be introduced and how they should be used in an ESL classroom. Those authors who support the use of authentic materials have in common one idea: "exposure". In other words, the benefits students get from being exposed to the language in authentic materials (Wekster, 2004).

Authentic materials are not only used by natives but also by non-naive teachers. To improve ESL learners' performance, it is better to use such materials that can provide them life-oriented experience and for this purpose authentic material is useful. So the researchers will do study in the same manner. They think that above two mentioned writers are correct in their approach and authentic materials can improve comprehension of ESL learners at intermediate level.

\section{OBJECTIVES OF THE STUDY}

The objectives of the present study are based on the use of authentic materials:

1. To improve ESL students' performance.

2. To develop ESL students' comprehension skill.

3. To improve ESL learners' four skills of English language.

\section{RESEARCH QUESTIONS OF THE STUDY}

Following were the main questions of the study:

RQ1: Does there exist any significant difference between gender performance in pre-test of controlled and experimental groups?

$\mathrm{RQ2}$ : Does there exist any significant difference between students' performance in pre-test and post-test?

RQ3: Does there exist any significant difference between male students' performance in post-test of 
controlled and experimental groups?

RQ4: Does there exist any significant difference between female students' performance in post-test of controlled and experimental groups?

\section{REVIEW OF RELATED LITERATURE}

There are two main groups of people in Pakistan relating to English language learning and teaching. One wants English as a medium of instruction and the other does not. However our students are familiar with English from the very beginning of their academic years because it is introduced as a compulsory subject. English language learning and teaching is of greater importance. Elite classes of the society use it as a source of communication. Middle class finds it necessary and unavailable since it is a successful step for effective communication. English language teaching (ELT) involves all the four skills (listening, speaking, reading and writing). In order to improve the language on the whole, it is essential to have a scheme for students in which they participate and improve their four skills.

Effective communication can only take place when there is a systematic development of all the language skills (Frier, anonymous). In order to improve ELT situation and improving students' comprehension skill, teachers have to use authentic materials in their classes. The important thing to start with is to narrow down the meaning of authentic materials'. Yes, it is obviously a worthwhile thing for the students to have meaningful experiences in the classroom, to make language learning an educational process of selfdevelopment the discovery as well as the learning of a language tool (Thorndike, 1999).

But this has little or nothing to do with authentic materials. For using authentic materials simply means using examples of language produced by native speakers for some real purpose of their own rather than using language produced and designed solely for the classroom. Of course, the focus should be on teaching language, not on literature. Chaves (1998, p. 11) also concluded that "the authentic input allowed learners to focus on a wider range of materials \& it had beneficial effects on the learners' development of communicative competence".

The impact of AM was further elaborated by giving a solid logic as students usually have trouble understanding texts outside the classroom because classroom reading materials do not reflect the language of the real world (Ur, 1996). It has also been asserted that authentic materials should remain a critical component of language programs (Berardo, 2006). In this regard, Hadley (2001, p. 97) concluded that the "Use of real or simulated travel documents, hotel registration forms, biographical data sheets, train schedules, authentic restaurants menus, labels, signs, newspapers, and magazines will acquaint students more directly with real language than any set of contrived classroom materials used alone".

A learner learns a language while hearing it, and then he does practice while reading, writing and speaking. $\mathrm{He}$ understands a language in situation within his personal experience. Thus the more pupils do practice, they learn it more (James, anonymous).

\subsection{Selection of Authentic Materials and its Use in the Language Classroom}

The first criterion is motivation or the exercises that can be done with motivation. Either the teacher has to use things which are as up-to-date as possible or which have a timeless quality about them (Arnold, 1985). Secondly, they have to be organized in some way. There is nothing worse than entirely disconnected bits of authentic language that are not linked to other aspects of the teaching. Lastly, they have to be selected in terms of their language and content (Thorndike, 1999).

According to Medly (1987), the use of authentic material as closely associated with the development of the communication approach to language teaching". It is stated that videotaped material offers more clues for comprehension to the students than other materials because of the visual controls and nonverbal clues. Books are also very important source to get knowledge of a language. As well as newspapers are also very important. Many foreign language learners in the beginning level are not accustomed to the normal speed conversation of native speakers. Authentic materials may present various challenges to students who are accustomed to take speech. Frier says, "Speech is the most important aim in language teaching". So, authentic material plays very important role in learning a language.

\section{DIFFERENT KINDS OF AUTHENTIC MATERIALS}

Authentic materials are good tools for language teaching and learning because they are interesting, motivate the learners, provide authentic culture information, exposure to real language, close to learners' needs, and support a more creative approach to teaching (Anderson, 1985). There are various types of authentic materials that a teacher can use in his class (Share \& Stanorish, 1983). They are stories, Newspaper, texts, 
cartoons, radio, and posters. The result of this study is also helpful for teachers because they can learn that how much authentic materials are useful for teaching ESL learners. While using authentic materials they can improve ESL students 4 skills. Students feel more comfortable in such classes where authentic material is used frequently.

\section{RESEARCH METHODOLOGY AND PARTICIPANTS}

It is very essential for the teachers to adopt as many ways as possible to let inter level students practice English in class. We believe that the success of this teaching strategy is mainly due to the fact that the learners can choose what they want to read, listen to, watch, and talk about in class. The researchers tried to get the results through quantitative research being focused on improving the students' ability to comprehend comprehension skill of English using authentic materials.

Present study was an experimental research. For this purpose experimental research design was used. Fifty students were divided into controlled group and experimental group. The independent variable of this research was "use of authentic materials" and dependent was "performance of the ESL students in comprehension skill of English." A test as tool was used to collect data from students about the use of authentic materials.

Sample of the students was consisted of mixed ability students. The population was consisted of all the students enrolled at intermediate level in Govt. S.E. college, Bahawalpur. Fifty students were taken as sample and divided into controlled and experimental groups. Controlled and experimental groups were taught English. Authentic material was used in experimental group while controlled group was taught in a simple method without using authentic material. They were taught by the researchers. The duration of using authentic materials was two weeks. The duration of class was two hours daily. So there were twelve classes that were conducted in total.

\section{PRE-TEST}

A pre-test was prepared to check the comprehension skill of students. A paragraph was chosen and given to the students. The questions were mentioned at the end of the paragraph. The time was 30 minutes for solving that test. Data of pre-test was collected from the students.

\section{POST-TEST}

A post-test of the same level of difficulty was prepared after two weeks of the experiment. The same test was given to both controlled and experimental groups. A comprehension passage was selected with questions. Then data was collected and test was marked accordingly.

\section{COMPREHENSION MATERIALS}

Twelve types of comprehension materials were designed to teach experimental group. Both groups were given same materials but in experimental group, authentic material was used to check whether authentic material helps intermediate students to improve their comprehension skill.

\section{DATA ANALYSIS OF PRE-TEST AND POST-TEST}

In order to find out the answer of first question, a paired sample t-test was conducted to evaluate the effects of authentic materials on comprehension skill of ESL students, using the pre-test and post-test score.

$R Q 1:$ Does there exist any significant difference between gender performance in pre-test of controlled and experimental groups?'

Table 1

Overall Results for Pre-test in Experimental and Controlled Groups

\begin{tabular}{|c|c|c|c|c|c|c|}
\hline Tests & Gender & $\mathrm{N}$ & Mean & Std. D. & t-value & Sig. \\
\hline \multirow{2}{*}{ Pretest Control group } & Male & 25 & 64.35 & 9.75 & \multirow{2}{*}{.179} & \multirow{2}{*}{.859} \\
\cline { 2 - 6 } & Female & 25 & 63.75 & 13.87 & & \\
\hline Pre-test Experimental & Male & 25 & 69.62 & 7.72 & -.186 & .853 \\
\hline
\end{tabular}




\begin{tabular}{|c|l|l|l|l|l|l|}
\hline Group & Female & 25 & 70.25 & 14.88 & & \\
\hline
\end{tabular}

In Table 1, the analysis shows no significant change between pre-test controlled group males $(M=64.35$, SD $=9.75)$ and females $(\mathrm{M}=63.75, \mathrm{SD}=13.87), \mathrm{t}(24)=.179, \mathrm{p}>.05$. Pre-test experimental group males $(M=69.62, S D=7.72)$ and females $(M=70.25, S D=14.88), t(24)=-.186, p>.05$. Thus, the research question that 'does there exist any significant difference between gender performance in pre-test of controlled and experimental groups?' answered in negative. Both groups have equal performance in both tests.

$\mathrm{RQ2}$ : Does there exist any significant difference between students' performance in pre-test and post-test?

Table 2

Paired Samples Statistics between Pre-test and Post-test Performance

\begin{tabular}{|c|c|c|c|c|c|c|}
\hline Tests & Mean & $\mathrm{N}$ & Std. D. & df & t-value & sig. \\
\hline Pretest & 64.05 & 50 & 11.87 & \multirow{2}{*}{49} & -3.720 & $.001^{* *}$ \\
\hline Posttest & 69.93 & 50 & 11.74 & & & \\
\hline
\end{tabular}

${ }^{* *} p<0.01$

In Table 2, the analysis expose a prominent variance between pretest group $(M=64.05, S D=11.87)$ and posttest group $(M=70.25, S D=14.88), t(49)=-3.720, p<.01$. Thus, the research question that, 'Does there exist any significant difference between students' performance in pre-test and post-test?' answered in positive. The mean score shows that posttest group has performed better as compared with pre-test ESL learners. The eta squared statistics $(0.21)$ indicated a moderate effect. From the findings it is clear that authentic material helps in improving performance of students.

RQ3: Does there exist any significant difference between male students' performance in post-test of controlled and experimental groups?

Table 3

Comparison between Post-test Controlled and Experimental Groups for Males

\begin{tabular}{|c|c|c|c|c|c|}
\hline Males & Mean & $\mathrm{N}$ & Std. D. & t-value & Sig. \\
\hline $\begin{array}{c}\text { Posttest Control group } \\
\begin{array}{c}\text { Posttest Experimental } \\
\text { group }\end{array}\end{array}$ & 64.35 & 25 & 9.75 & & \\
\cline { 2 - 4 } & 69.62 & 25 & 7.72 & -2.036 & .053 \\
\hline
\end{tabular}

In Table 3, the analysis shows no conspicuous change between males posttest control group $(M=64.35$, SD $=9.75)$ and posttest experimental group $(\mathrm{M}=69.62, \mathrm{SD}=7.72), \mathrm{t}(24)=-2.036, \mathrm{p}>.05$. Thus, the research question that, 'Does there exist any significant difference between male students' performance in post-test of controlled and experimental groups?' answered in no. Both groups have equal performance in post-test.

RQ4: Does there exist any significant difference between female students' performance in post-test of controlled and experimental groups?

Table 4

Comparison between Post-test Controlled and Experimental Groups for Females

\begin{tabular}{|c|c|c|c|c|c|}
\hline Females & Mean & $\mathrm{N}$ & Std. D. & t-value & sig. \\
\hline Posttest Control group & 63.75 & 25 & 13.87 & -3.481 & $.002^{* *}$ \\
\hline
\end{tabular}




\begin{tabular}{|c|c|c|c|c|l|}
\hline $\begin{array}{c}\text { Posttest Experimental } \\
\text { group }\end{array}$ & 70.25 & 25 & 14.88 & & \\
\hline
\end{tabular}

${ }^{* *} \mathrm{p}<0.01$

In Table 4, the results reveal a notable difference between female posttest control group $(M=63.75, S D=$ 13.87) and experimental group ( $M=70.25, S D=14.88), t(24)=-3.481, p<.01$. Thus, the research question that, 'Does there exist any significant difference between female students' performance in post-test of controlled and experimental groups?' answered in yes. The mean value of the results shows that experimental group has performed better as compared with control group female students. The eta squared statistics $(0.30)$ indicated a moderate effect. From the findings it is clear that authentic material helps intermediate students to develop their comprehension skills.

\section{FINDINGS}

No significant changes were seen between pre-test controlled group and experimental group. In the analysis of post-test there exposed a prominent variance between pre-test and post-test group. The mean score shows that post-test group has performed better as compared with pre-test ESL learners. The eta squared indicated a moderate effect size. From the findings, it is clear that authentic material helps in improving performance of students. On the basis of gender no conspicuous change was found for males' post-test controlled group and post-test experimental group. However, there reveal a notable difference between female post-test controlled and experimental group. Experimental group has performed better as compared with controlled group female students. The eta squared statistics $(0.30)$ indicated a moderate effect. From the findings it is clear that authentic material helps intermediate students to develop their comprehension skills.

\section{CONCLUSION}

Authentic material encourages and motivates the students to take interest. Change in teaching techniques proves to be productive. The results of pre-test and post-test have shown the difference between the performances of both groups. So the researchers' question proved correct that authentic material is useful for understanding comprehension skill of English.

\section{RECOMMENDATIONS}

Teachers need to develop their own proficiency in English so that they can pass on a good model of English to their students. While using authentic materials, they can improve the performance of the students in comprehension of English.

\section{REFERENCE LIST}

Emerson, R. W. (2004) Creating positive attitude toward English as a foreign language. Efonem, vol-44 no4.

James, P. (anonymous) Second language teaching Method, Principles procedures. San Diegolstate unikerst.

Wekster, N. (2004) Language and learning third editi). Australia. Oxford University Press.

Anderson, H. C. (1985) Techniques in language teaching. Oxford

Arnold, E. (1985).A division of hodder and Stoughton. LONDON MILBURN

Thorndike, E. (1999) A course in language teaching-trance. Book Cambridge university press.

Medley. (1987) The practice of English language teaching. Longman Printing press limited,

Share \&Stanorish (1983) A training Course for TEFL. Oxford University Press

Frier. (Anonymous) Teaching of English as a second language. London Longman publishers

Adams, T. (1995) What Makes Materials Authentic? (ERIC Document Reproduction Service No. ED 391389).

Chaves, M. (1998) Learner's perspectives on authenticity. IRAL, 36(4), 277 - 306.

Guariento, W., \& Morley, J. (2001) Text and task authenticity in the EFL classroom. ELT Journal, 55(4), 347-353. 
Hadley, A. (2001) Teaching language in context (3rd edition). London: Longman.

Harmer, J. (2001) The practice of English language teaching (3 ${ }^{\text {rd }}$ edition). London: Longman.

Miller, M. (2005) Improving aural comprehension skills in EFL, using authentic materials: An experiment with university students in Nigata, Japan. Unpublished master's thesis. University of Surrey, Guildford, UK. 